FORUM 


\title{
The Greek economic crisis as trope
}

\author{
Daniel M. Knight
}

\begin{abstract}
The Greek economic crisis resonates across Europe as synonymous with corruption, poor government, austerity, financial bailouts, civil unrest, and social turmoil. The search for accountability on the local level is entangled with competing rhetorics of persuasion, fear, and complex historical consciousness. Internationally, the Greek crisis is employed as a trope to call for collective mobilization and political change. Drawing on ethnographic research conducted in Trikala, central Greece, this article outlines how accountability for the Greek economic crisis is understood in local and international arenas. Trikala can be considered a microcosm for the study of the pan-European economic turmoil as the "Greek crisis" is heralded as a warning on national stages throughout the continent.
\end{abstract}

Keywords: accountability, economic crisis, Greece, neoliberalism, political mobilization

\section{The Greek economic crisis as trope}

As the ramifications of a second multibillioneuro bailout are deliberated by the Greek government and new waves of austerity enswathe the nation, people are left to ponder where it all went wrong. Blame is directed at the external Other-America, Germany, and the infamous Troika-and the "Other within"-corrupt politicians, businessmen, and broken neoliberal promises (Kirtsoglou and Theodossopoulos 2010; Herzfeld 2011). Financial mismanagement and "corruption" at the governmental level are rife, but a pyramid effect of dangerous economic activity is now widely acknowledged, as neoliberal rationale entwines with "traditional" economic relations from the heights of government to the grassroots level (Narotzky 1997; Knight 2012b). However, the Greek economic crisis transcends local and national borders. With escalating global social unrest and the circulation of blame spawning niche political parties pandering to xenophobia, the "Greek crisis" highlights the complex relationship between global systems and local experience. Across Europe the adoption of the Greek crisis as a trope to provoke fear and stimulate shifts in the realms of governmental power further emphasizes the uneven nature of the international political theater.

Narratives of blame have been formulated by the European right and directed at specific nation-states based on essentialist ideas of culture and economy. This methodological nationalism 
seeks to clarify abstract global flows of finance and accountability by making examples of peripheral states, thus distracting from substantial economic troubles at home. The focus on Greece as the par excellence example of cavernous corruption, economic extravagance, and social unrest has been manufactured in northern Europe to distract skeptical publics from controversial budget cuts in nations such as France, the Netherlands, and the United Kingdom. Furthermore, the spotlight on Greecerepresenting 1.9 percent of European Union (EU) gross domestic product (GDP) in 2010 (Greek GDP contracted a further 6.9 percent in 2011) ${ }^{1}$ (Bloomberg, 13 May 2011)-disguises equally significant problems in larger European economies such as Italy and Spain, which have received markedly different treatment from the eurozone. This form of "manufacturing" could be understood as part of an ideologically driven intentional campaign of "erasing and remaking the world" in the mold of neoliberalism ${ }^{2}$ (Klein 2008: 3; Harvey 2005; Ortner 2011). Greece is portrayed as a cause rather than a symptom of the eurozone crisis, covering flaws in wider reaching European systems (Pryce 2012: 101).

While it could be argued that the crisis is ultimately rooted in an imbalance of financial markets, this article focuses primarily on how the Greek economic crisis is employed as a metaphor scaling the levels of local experience and international anxiety (Miller 1995). Since 2003 I have been engaged in ethnographic research in Trikala, central Greece. My fieldwork spans a period of dynamic social change, as years of economic prosperity have given way to crisis and austerity. The town, which has a population of 51,862 , is a microcosm for understanding the pan-European crisis, in which global economic trends that resonate throughout the continent are played out. Often, local narratives paint a contradictory picture of everyday life, capturing multiple forms of crisis experience (Gilsenan 1996: 57). However, since summer 2011 a startling development in the Greek crisis has been the impact on peripheral areas, where the search for food and shelter has become as prominent as in the urban centers of Athens and Thessa- loniki. This is due to the draining of resources from extended family networks, previously used as the primary coping strategy buffering financial destitution (Knight 2012b). Thus, in peripheral regions the severity of crisis continues to escalate.

\section{The crisis and financial markets}

Various time lines place the start of the Greek crisis at different points. Specialist financial news outlets tend to focus on precise technical indicators, whereas newspapers embroider a longer narrative. For example, Bloomberg starts its time line with the inability of the PASOK government to fulfill its promise to reduce the budget deficit within twelve months when it came to power in October 2009. The Financial Times starts the crisis on 8 December 2009, when Fitch cut ratings on Greek debt to BBB plus with a negative outlook, prompting heavy selling of Greek stocks and bonds (The Financial Times, 21 October 2011). ${ }^{3}$

Newspapers and radio sources tend to embellish the crisis as a more elaborate story involving earlier antecedents and parallels. Thus, newspapers such as the Daily Telegraph and The Guardian begin with a weak Greece joining the eurozone in January 2001, followed by a blowby-blow account of events since (The Telegraph, 16 June 2011; The Guardian, 5 May 2010). ${ }^{4}$ Further historical analysis by academics and political analysts place the cause of the crisis in unregulated liberalization commencing with Greek accession to the European Economic Community (later to become the European Union) in 1981, only seven years after the fall of the military dictatorship and associated structured economics (Knight 2011; cf. Klein 2008: 155-168). It is important to distinguish between what for financial analysts are the key drivers in this trajectory for risk assessments, which are the yield on ten-year Greek government bonds jumping from 5 percent at the end of 2009 to close in on an unsustainable 20 percent by mid-2011. By 13 June 2011, S\&P had downgraded Greece's credit rating to CCC, four steps from default, and the 
lowest for any country in the world, reflecting their view that "there is a significantly higher likelihood of one or more defaults" (Reuters, 13 June 2011). ${ }^{5}$ Another popular measure for likely default is the spread investors demand to hold Greek ten-year securities instead of similar maturity German bonds, which had climbed to a historical high of over 14 percent by mid-2011.

Financial analysts will typically report how close Greece is to "sovereign default" as the result of these yields: the higher these are, the more they indicate a lack of confidence by markets in the ability of Greece to repay its debts. If it rises too high, the government will no longer be able to raise the funds necessary without paying punitive rates of interest, which then will threaten the entire nation's viability. There is much media speculation that if Greece can no longer rein in expenditures to meet its obligations, there will be blood on the streets, with some extreme theories speculating civil war, military dictatorship, and eurozone collapse.

Austerity measures and fear of return to a weaker currency mean that wealthy savers and investors are gradually withdrawing their funds from Greek banks and placing investments abroad in stronger foreign currencies. In mid2012 there is still talk of the Greek banking system "collapsing." Financial reporting today refers to the Greek crisis as “Europe's Lehman's moment" (Gilbert and McCormick 2011), in reference to the parallel with events in the United States in 2008 that triggered the worldwide crisis. There is reference to "Armageddon scenarios" across Europe should the Greek government negotiating austerities and bailouts fall in favor of seeking to default on its loans, as was narrowly avoided in the May and June 2012 general elections.

Clearly, such references by financial markets to the possibility of sovereign default are very real and threatening insofar as they shake markets and investor sentiment worldwide, and affect elections throughout the European area. This is especially pertinent in states such as Germany, which is expected to raise the majority of funds for the bailouts, and France, which carries the biggest banking sector exposure to
Greece of any European country. The fate of the euro, the European Union, and the financial viability of individual countries are also claimed to be at stake. This is why the Greek crisis has become a significant issue for all European countries and, indeed, internationally. The "Greek crisis" has thus been successfully initiated as a meaningful trope spreading uncertainty and fear throughout the continent.

\section{The situation in Trikala}

In Trikala, the crisis is experienced at many levels, from rising supermarket prices and fuel scarcity to the fear of returning to famine and eras of colonization (Knight 2011, 2012a). Austerity measures create a tangible sense of destitution and persecution, with growing unemployment and frequent family feuds, meaning the present crisis is increasingly thought of in terms of previous ones, such as the Great Famine of 1941 to 1943 and the Axis occupation. This has a unifying effect, as people believe that as previous eras of hardship have been overcome, so will the current crisis. There is also much cynicism as to the causes of and possible solutions to the crisis and the role of external forces in dismantling the state for future accumulation (Harvey 2003; Clarke 2008: 136). The dispossession of public, and sometimes private, property toward international investors constitutes an elaborate privatization program deemed necessary as part of the Troika-enforced economic reforms. However, this does not sit well with local historical consciousness and has become shrouded with conspiracy theories disseminated through the mass media (Pelkmans and Machold 2011).

Debates concerning blame and accountability for the crisis spill over from the public to the private domain. Hence, locals "gather outside" (mazevonde ekso) to escape the stresses of the home and endless media coverage of the crisis. The topic of conversation invariably turns to accountability for the economic situation. A narrative from a private business owner in Trikala is representative: 
We are discussing the crisis with other shop owners in the neighborhood-the photographer, the driving instructor, the pizza place. We congregate outside of our stores during the day and discuss the situation of the economic crisis and the fact that we do not have work. Five businesses have closed on this one street in the past three months, yet not one of the politicians in Athens is prosecuted for causing this mess. What is going to happen? ... I do not watch television because I am so stressed, I have constant headaches. We gather outside in the evenings and share our stories. We discuss who got us into this crazy situation and what to do next. Some of my friends go to protests in Athens, but generally we feel the periphery is being forgotten as you only ever hear stories of Athens ... We are going crazy here, the constant coverage on the television, the stories of disaster, of crisis, everybody is afraid ... Some people have been driven to suicide and yet nobody is paying for these lost lives. (Anita, thirty-eight, Trikala, August 2012)

Suicide caused by economic hardship is more than merely local mythologizing (Knight 2012b). A previously taboo subject in rural Greece, suicide is now very much part of local reality. In summer 2012 high-profile cases of suicide discussed in the media resonated with four cases within the space of a month in Trikala alone. Without exception, the person left behind a note stating financial ruin and hunger as the "cause of death."

Initial blame is regularly directed toward the authoritarian external Other, such as the European Union, Troika, and the United States, for forcing austerity upon Trikalinoi. These bodies make "decisions of global consequence (that) shape the face of the world" (Werbner 1995: 84; Herzfeld 1992; Kirtsoglou and Theodossopoulos 2010). However, Trikalinoi are also critical of the Other within, those who sell out the "Greek people" to foreign demands. Elisabeth Kirtsoglou and Dimitrios Theodossopoulos outline how Western interference fans antiglobalization sentiment that breeds "indigenous reaction to centres of power” (2010: 85; see also Kalb 2009).
In a similar way, Trikalinoi view politicians in Athens, who sanction Western interference and benefit financially from international collaboration, as the "hands that lead" or "defy" the Other (Herzfeld 1992: 81). Conspiracy theories concerning global power are merely one aspect of a much deeper understanding of accountability that incorporates overt historical consciousness and media influence (Pelkmans and Machold 2011; cf. Sutton 2003).

The global impact of "mediascapes" (Appadurai 1990) surrounding the Greek crisis is striking, and Trikalinoi are well aware of the media representations beyond national borders. Capturing the fluid and irregular cultural flows characteristic of international capital, Arjun Appadurai (1990: 9) defines mediascapes as referring "both to the distribution of the electronic capabilities to produce and disseminate information ... which are now available to a growing number of private and public interests throughout the world, and to the images of the world created by these media." In northern Europe the Greek people are portrayed as being equally accountable for the current financial situation due to their open participation in "corrupt" practices and "lazy" work ethic.

Nikos, an elderly farmer, explains how Trikalinoi are conscious of how the crisis is being portrayed in the national and international media:

Nikos: Even our own prime minister [at the time, Giorgos Papandreou] doesn't care about us. He does what the Americans say ... they can afford new American military aircraft, but the elderly women cannot be treated by the doctors because they can't pay the bribes. Elderly women still live alone up in the mountain villages, they have no central heating and no running water, but the prime minister does not care as long as he gets money from the Americans and the EU, as long as he holds on to power. And just look at the condition of the roads around here. They were supposed to have been fixed ten years ago but they started-with money from Europe-and then mysteriously stopped again, half finished ... Our government is 
also a bad guy in the story, you cannot blame only the Americans or Germans, they know that they can get money out of us so they take advantage ... our prime minister will slap them on the back and blow them a kiss ... All Greek politicians are the same, as long as they fill their own pockets ... they are responsible for the crisis yet none are prosecuted.

DK: But should the everyday Greek people take some of the responsibility for the economic crisis? Were they engaged in similar activities to the politicians and people that you are criticizing?

Nikos: This is how it is portrayed in Europe, but we, the little people (laoutzikos), are the ones with no money, the ones that suffer the consequences ... Yes, some people participated in not declaring some of their income for tax, and others claimed pensions for deceased relatives, but really this is nothing compared to the amounts the politicians were concealing ... But the "bad Greek people" is emphasized by European politicians and newspapers ... We are well aware of what they think in northern Europe, including you in England. [You believe] [i]t is our fault, we are lazy, greedy, and we are corrupt ... we enjoy the "good life". Maybe there is a small truth in that-this is part of the system-, but we little people are now the only ones that are suffering from the austerity and financial punishments ... the "elites" are getting away free.

As economic ruin tightens its grasp on peripheral areas across Europe, Trikalinoi regularly call for political "elites" to be held responsible for the "crusade of greed" (Ortner 2011) that provoked the most significant consequences of crisis. They acknowledge that many economic processes are endemic in Greece, causing a pyramid effect of "suspect" economic relations embedded within the ambiguous relationship between neoliberal and traditional ideals. $\mathrm{Pa}$ tronage and favor exchange are part of everyday life in Greece, from national government to the grassroots level, emphasizing the necessity to view neoliberalization as a historical process with localized nuances (Peck and Theodore 2012: 177; Wacquant 2012). So far, only a handful of individuals have faced the consequences of their actions. One such case was the highprofile arrest of former defence minister and a founding member of the PASOK party, Akis Tsochatzopoulos, in April 2012. Mr. Tsochatzopoulos is accused of heading a money-laundering racket over the course of two decades. This arrest is perceived by Trikalinoi as a "token gesture" aimed at satisfying the public demand for retribution, and the timing of the arrestless than a month before the general electionis viewed with suspicion. Even after the election of Antonis Samaras as prime minister of a proausterity coalition government in June 2012, grand narratives disseminated through mediascapes (Appadurai 1990: 7) have failed to divert blame away from political elites perceived as the pinnacle of neoliberal ideals of accumulation and dispossession (Harvey 2005: 159-164).

The activities of the laoutzikos through thirty years of economic prosperity are not understood as blameworthy within the wider context of political accountability. Protests demanding the installation of $O$ Allos (the Other, someone else, implying none of the present political figures) to government continue, and as early as 2009 had spread beyond the urban centers. In a striking parallel, during the Argentine economic crisis of 1998-2002, while demanding a completely new government to be installed, protestors adopted the slogan "They must all go-not a single one should stay" (Goddard 2006: 271); the country had five presidents within two weeks (Page 2009: 1; Goddard 2010: 131-132).

For Giota, sixty-six, the impact of austerity could not be more vivid.

Giota: Opposite my house they have begun constructing a prefabricated building as an extension to the current school. It is to accommodate children from seven of the surrounding villages where schools are being 
closed down. I used to be a teacher and I have learned through my networks that the schools will be closed and the majority of teachers will lose their jobs. The unemployment here is already very high; both my nephews are unemployed despite having excellent university degrees and my brother lost his job two years ago. He borrowed a lot of money from his extended family in order to pay back outstanding loans and even had to sell his home ... The government says that it is necessary to cut jobs but are offering no alternatives for these people. There is no real benefit system like you have in England and people of all ages are unemployed and with no future prospects. Even retired people like me have only one-third of our original pension, yet supermarket prices keep on going up. In some cases people are being driven to suicide.

DK: Do you know any cases of recent suicides in Trikala?

Giota: Two people I knew from the neighboring village have taken their own life within the past two months. One man shot himself after his son lost his job and was unable to pay his bills. He said to my friend that he could not face seeing his son starve to death so invited him [the son] for a final family meal and then went to the shed and shot himself in the head. This came only six weeks after another man from the same village also committed suicide after losing his job last year. He could not live with the shame of being unable to feed his family after they lost their home ... My own son's job is precarious and I now live daily in fear for his life.

The impact of economic crisis on the regularly overlooked Greek periphery is rapidly escalating. Hunger, suicide, and homelessness are now tangible (see Knight 2012b). The rhetoric emanating from northern Europe that "the people" of Greece are responsible for the turmoil is acknowledged locally, but not accepted while there continues to be a noticeable lack of ac- countability at the top of government. The "image-centered, narrative-based accounts of strips of reality" offered through mediascapes form partial truths rich in political ideology and metaphor and crafted toward their target audience (Appadurai 1990: 10).

Concerns of northern European governments to maintain control of the Greek political situation were highlighted in the media during the Greek general elections of May and June 2012 when the popular anti-austerity leftist SYRIZA party was portrayed in British, French, and German media as 'radical communists', or the 'extremist far left equivalent to the neo-Nazi Golden Dawn.' Local people became aware of this portrayal of the left on the international stage and grew increasingly disheartened with what they perceived as foreign meddling in national affairs. By offering an alternative solution to the crisis, SYRIZA was seen as a tangible threat to European-enforced austerity. Unfavorable images of a radical far left were part of a strategy "orchestrated from the major epicentres" of neoliberal power in an attempt to fashion opinion at the grassroots level (Harvey 2005: 88; see also Wacquant 2012: 69). Some locals compared this anti-left rhetoric as akin to the interference of foreign governments in the 1940s civil war.

\section{Metaphors of history and crisis}

The Greek crisis in and of itself has become a poster boy for governmental mismanagement, unregulated markets, corruption, and capitalist intemperance. In northern Europe, blame is attributed squarely to Greek citizens and their government, with layers of rhetoric constructed and disseminated globally as part of the "management and manipulation" of crisis (Harvey 2005: 162). Enduring and iconic verbal and visual imageries are constructed around this critical event (Das 1995; Goddard 2006, 2010: 131). The metaphor of the Greek economic crisis is employed in Europe as a threat of dispossession and failure if sociopolitcal reform is avoided (cf. Kalb 2009). Panic and fear spread through un- 
contextualized claims stimulate public interest, contradicting the commonplace "disenchantment with public politics widespread in modern democracies" (Narotzky and Smith 2006: 170).

On an international level, the messages emanating from Greece of protests, rioting, and strikes have been at the fore of media reports for nearly four years. ${ }^{6}$ Unexpected and seemingly endless claims made on the funds of already hard-pressed countries for the bailouts of Ireland, Portugal, and Greece through the International Monetary Fund and the European Union have placed this issue foremost on the agenda of each European Union nation and also in the United States. Fear of contagion to other poorly rated countries and a domino effect of sovereign insolvencies with banks heavily exposed to Greece have recently inflated the situation of macropolitical instability further still (Peck and Theodore 2012: 178). The "Greek crisis" thereby becomes a political trope (Fernandez 1986, 1993), a persuasive "story seed" (Carrithers 2007:

2) deployed by national governments drawing on a rich pool of metaphors and narratives to shock national populations.

Greek national identity is "defined by a perceived set of universal political and economic circumstances" - in this case, crisis (Chomsky 1996: 95; cf. Hamilakis 2003; Bryant 2004; Theodossopoulos 2007: 12). Yet, as Noam Chomsky notes, many paradoxes fill the voids between rhetoric and reality (1996: 100-101). The reality on the ground is not as monodimensional as portrayed through international media and political rhetoric. As I have argued elsewhere, the crisis has raised questions of (poly)temporality, as contemporary social turmoil is embodied alongside past crises such as the Great Famine of 1941 to 1943, periods of occupation under Ottoman and German rule, and the late 1990s stock market crash (Knight 2012a, 2012b). Trikalinoi may claim they are reliving the era of starvation enforced during World War II, and that land worked by one family for over five hundred years has been claimed by opportunistic foreign investment companies in a form of "occupation". Indeed, the fact that a critical situation is presented as simple at all must raise sus- picion. Nevertheless, the images circulated internationally claim an objective critique of a monolithic event-the Greek crisis-disguising the intricacy of current local circumstances. This highlights on a macro level the complex process of social destruction and reformation caused by economic crisis. The crisis has also created dynamic spaces for political resistance, business opportunism, and diversification programs, as well as destitution and downward social mobility (Knight 2012b).

The Greek crisis is employed as a trope in the political theaters of Europe as a shock tactic to justify sociopolitical change. The notion of a fresh start in order to avoid economic disaster ("on the scale of Greece") is promulgated to serve many purposes. The metaphor of the Greek crisis is used to "help people persuade themselves" of the need for change (Chomsky and Barsamian 2001: ix). Through inciting fear based on the rhetoric of crisis and insecurity, many neonational political aspirations are also achieved (cf. MacGaffey 1998; Kalb 2009). Mediascapes are here employed not only to pacify separatists, as Appadurai (1990: 13) suggests, but also to rouse activism and resistance by disseminating theories of impending devastation.

Mathijs Pelkmans and Rhys Machold (2011: 66-71) have argued that theories of conspiracy and countertruths should be evaluated within the sociopolitical fields through which they travel. The collusion of political forces to spread fear among European publics has flourished at a time when there is a palpable discrepancy between political rhetoric and experienced social reality. With ongoing pan-European socioeconomic transformations there are numerous competing claims to truth and persecution infused with varying degrees of political credibility. But as demonstrated by the implementation of sweeping Troika reforms, there is rarely any space to consider the deep cultural and historical nuances of the Greek situation.

The trope of the Greek crisis is especially prominent in election contexts. When newly elected governments deal with the legacy of predecessors, the rhetoric of crisis initially ceases to be wholly detrimental, as it is propagated as 
the blemish of the previous administration. Blame can for a time be successfully located away from recently incumbent governments. Coming to power in October 2009, Greek prime minister Giorgos Papandreou (PASOK) blamed the falsification of deficit statistics on the previous New Democracy government of Konstantinos Karamanlis (2004-2009). Papandreou claimed to have uncovered the "true" deficit of 13.6 percent when taking office; it had been estimated at 1.8 percent the previous year. The majority of Greeks initially accepted the news with the resignation that greets all exposures of corruption, for it is common knowledge that elements of the government "eat money" (trone lefta).

However, when the ramifications of the turmoil became apparent in the form of financial bailouts, job losses, wage cuts, and austerity measures, the Papandreou administration came in for increasing public criticism. The mood in Trikala reflected the national trend as people generally became disinterested in using Karamanlis as the target toward which to vent their mounting frustrations; blaming the previous government was no longer a politically viable option. Over the course of three years Papandreou became the focus of the majority of internal censure, while blame directed away from the nation-state became infused with notions of colonization and occupation.

Former deputy prime minister Theodoros Pangalos infamously placed the blame for financial crisis on the Germans: "They [the Nazis] took away the Greek gold that was in the Bank of Greece, they took away the Greek money and they never gave it back ... I don't say they have to give back the money necessarily but they have at least to say 'thanks."'7 The former mayor of Athens, Nikitas Kaklamanis, also waded into the dispute: "You [Germany] owe us 70 billion euros for the ruins you left behind [in the War]" (BBC News, 15 February 2010; Knight 2012b: 65; also Pryce 2012: 33-34).

Local versions of this argument are not as crude, but resonate strongly with notions of colonization, colored with the local history of Ot- toman Ciftlikades (landlords of great landed estates) and Turkish occupation (Knight 2012b).

We are in the era of the new Ciftlikades. The collaboration between the Greek state and foreign investors is the same. We are given so many promises but we are being slowly invaded while our livelihoods deteriorate. Just like before, people are playing games and the workers of the land are left thinking of the past. The workers will have to rise up. (Dimitris, sixty-two, Trikala)

I researched my history. We are all descendents of the people who worked these plains. Now I can begin to understand what my ancestors went through [to fight for their land]. It is exactly the same. Our fields are being ruled by outside forces, we have no protection and people are taking whatever they can ... our own government and Europe ... to make as much money while they have the opportunity. I have nowhere to sell my produce so must give my land over to them. They are the biggest Ciftlikades ever and Greece has become the ciftlik of Europe. (Michalis, forty-four, Kalampaka)

This is another example of how Trikalinoi simultaneously direct their frustration internally and externally, but always with historical reference. Politicians and Ciftlikades are stereotypes of the "heartless system" (Herzfeld 1992: 80) that appeal to the collective imagery.

The theme of colonization has recently widened to include Germany, as local people and public figures continue to draw on historical notions of occupation, often temporally condensing the period of the Ciftlikades with German occupation (see Knight 2012b).

The Germans have capitalized upon the plight of all Greeks. They have bought our companies and held us to ransom. It is history repeating itself. The Germans do not want to compromise and will take everything they can from us. They caused us famine before; they will cause it again now. They treat Greece as their private ciftlik. I am told that if I can't sell my grain I can install 
photovoltaic panels on my land, but most of these companies are German-owned and using German products. It is another colonization, they are Ciftlikades and I don't want to just hand over all I own. (Giannis, forty-seven, Trikala)

Due to the ambiguous nature of transnational neoliberal markets, the consequences of economic crises are often portrayed as of common and collective responsibility. The causes cannot be realistically traced to a single state or political body alone, but blame can be transferred to numerous ambiguous sources where local and global historical narratives have merged (Miller 1995). Blame can be circulated as "poisonous knowledge" (Das 1995), often in the form of gossip and hollow language (Herzfeld 1992: 81) that aim to both relocate and disseminate the cause of the problem away from the Self. Accountability implies that someone(s) will be brought to justice, be held accountable. Yet there is little chance of individuals being held accountable for the Greek economic crisis. It is a complex sociohistorical milieu where the distinction between local and global forces and individual and collective responsibility is inevitably blurred.

\section{In the salons of Europe}

Around the globe the collective inchoate "we" has been incorporated into political rhetoric to address issues of accountability and mobilization (cf. Carrithers 2007, 2008). Responsibility for crisis is thus disseminated. In March 2009 the slump in the Italian economy led to former prime minister Silvio Berlusconi encouraging the Italian people to "go out and spend" to raise their nation out of economic squalor (di Leo 2009). This statement is embedded with market rationale: as the recession got worse, so the public experienced financial restrictions and duly spent less, only to further harm the economy. However economically viable this suggestion might have been, it certainly was not a good exercise in public relations on behalf of the Italian prime minister. In Britain, chancellor of the exchequer George Osborne's now infamous statement "we are all in this together" is surely one of the most explicit employments of the not-so-inchoate "we" of recent times.

Examples of rhetoric calling for collective mobilization in times of crisis are abundant. At the World Jobs Summit in Detroit in 1994 the US president announced that companies "must cooperate in facing their common problemunemployment-in much the way they have cooperated for fifty years to defeat Communism, to stand up against Iraqi aggression, and to expand the global trading system" (Campbell 2003: 3). This statement disseminated the responsibility for increasing unemployment away from the target of the White House and toward the collective Other. In another case, Bruce Campbell quotes the Mexican president as placing the "responsibility to reform" on the participation "of all political parties and of all society" (ibid.: 4). This demonstrates a shift in accountability from figures of political power to the people, and a preemptive warning that if the reform legislation fails then it is not the sole responsibility of the president. Hence, a feeling of self-responsibility was imposed upon the public; a sense of "taking care of yourselves" that provoked collective mobilization through rhetorics of crisis and fear of dispossession.

One comparative example of the implication of the "Greek crisis" as a political trope comes from the United Kingdom. During the 2010 election-against a background of expenses claims and over a decade of highly publicized political spin-the question was constantly posed as to whether Britain faced a similar fate to Greece. ${ }^{8}$ The public response was to generally cite media exaggeration that ignored "currents and counter-currents" of localized neoliberalization (Peck and Theodore 2012: 177; cf. Clarke 2008). Yet, fuelled by the imagery of rioting on the streets of Athens (screened live on numerous news channels), headlines focused on how "Britain is facing its own Greek tragedy" ( $B B C$ News, 28 April 2010). Opposition parties suggested parallels between the Greek situation 
and the potential fate of Britain. The Conservative Party continues to this day (October 2012) to frequently emphasize the difficulty in dealing with the remnants of Labour's economic mismanagement, underlining that their party alone is stopping Britain from sliding toward Greekstyle economic turmoil.

At the time of the UK 2010 election, any comparisons with Greece were dismissed by the then Labour foreign secretary David Miliband as "economic illiteracy." Nevertheless, the proposition would not disappear, as politicians attempted to discredit opponents and rally support by playing on popular ideas about the national and international political landscape (Pelkmans and Machold 2011: 68, 74). One week before the election, Vince Cable, then treasury spokesman for the Liberal Democrats, continued the "politics of fear" (Kalb 2009: 209) by warning that "the country risks following Greece into crisis" unless there is a change of government: "unless the next government gets seriously to grips with the deficit problems, as we're determined to do, we could have a serious problem.” Opposition leader David Cameron's line had a similar precautionary tone: "Greece stands as a warning to what happens if you don't pay back your debts ... You can't go on borrowing at this level forever" (The Times, 28 April 2010). The line coming from the unions concerning political change in times of economic uncertainty was more hard line: "If you want a snapshot of what we are facing take a look at what's happening in Athens today. Junk status, key services ripped to shreds and workers on the streets. Greece today-UK after May 6" (the date of the 2010 general election; Bob Crow, quoted in The Times, 28 April 2010). In October 2010 Conservative former chancellor of the exchequer Kenneth Clarke informed journalists of how dramatic spending cuts amounting to some $\mathfrak{£} 81$ billion over four years were necessary in order to save Britain from "the Greek alternative," reiterating remarks made in March that the United Kingdom was living on "borrowed time," only to be saved by new Conservative economic policy (The Guardian, 18 March 2010).

\section{Global legacies}

But what of the longevity of the "Greek crisis" as a political trope? Will this crisis remain associated with poor government, economic mismanagement, corruption, and public rebellion-a future reference point for impending crisis, as is the panic of 1907 or the Great Depression of the 1930s (cf. Hart and Ortiz 2008: 3)? Economic crises come and go, as attested by Southeast Asia (1997), Argentina (1998-2002), and Turkey (2000-2001). Like these events, the Greek crisis will occupy a limited time in the global public arena; its impact as a clutch phrase for political debate is finite, as neoliberal crisis continues on its messy trajectory through history and geography (Harvey 2005: 87; Peck and Theodore 2012: 179; Wacquant 2012: 69). The difference, however, is that this particular regional elaboration on a global crisis has significant transnational impact, with direct repercussions on the eurozone and European Union nations. Yet Greece represents a relatively small economy, a non-Anglophone nation that is experiencing its fifteen minutes of global infamy. The moment for political opportunism ${ }^{9}$ based on the international panic instigated by the Greek crisis will be temporary. The power of this trope has stringent temporal limits.

In Trikala, the current crisis will become part of historical experience, to be recounted as culturally integral sometime in the future (Goddard 2006: 268, 279). Themes of famine and colonization are prominent in the cultural repertoire of Trikalinoi and will possibly be employed once again to critique future political and economic situations. The crisis will remain as a constant point of historical reference even beyond the borders of Greece, the consequences of which will be at the fore of public imagery for decades to come. When the cultural patterns of Greek capitalist economics merged with downward global market trends, here commenced a perfect storm of personal and collective vulnerability, market instability, fiscal failure, and the search for ever elusive accountability. The "trope" is more than merely metaphor for Trikalinoi, as the peripheral town 
is a representative microcosm through which to approach global financial meltdown and rhetorics of fear and dispossession.

Commentaries on accountability are "fragmented, multiple, contradictory and semantically vague" (Kirtsoglou 2010: 168), often fusing local, national, and global discourses of crisis. Furthermore, temporal boundaries, as with those between the individual and the collective, are deliberately blurred. Yet there is an agreement that someone, somewhere, should be held accountable for the impact of economic crisis, leading to protests, strikes, and a feeling locally that Greece has been publicly shamed. On this basis, the Greek economic crisis has been employed as a trope for political change in other European contexts. The reality and rhetoric of the Greek crisis, disseminated through international media, have been used to incite global fear, panic, and the search for accountability. Caricatures of inept politicians leading the nation down a path to Greek tragedy are a common thread in accountability narratives particularly propagated by the European right on various international stages.

Circulating blame happens in a situation where problems are caused within the complex flow of capital in and around the financial crisis. Concurrently, the European Union, International Monetary Fund, and most political commentators continuously seek to make clear cuts in these global flows and assign blame on the basis of well-defined units, in particular nation-states. These units are then attributed a particular cultural character that essentializes the complexity of the situation. Such essentialism provides ammunition for the construction of tropes to provoke political change beyond national borders, as methodological processes of nationalism are bewitched by opaque transnational flows.

\section{Acknowledgments}

I am particularly grateful to Gustaaf Houtman for feedback on an earlier version of this article.
David Henig, Roger Just, Robert Layton, Stephen Lyon, Stavroula Pipyrou, and Dimitrios Theodossopoulos also provided very stimulating comments. I am indebted to Kevin Featherstone, Charles Stewart, and David Sutton for discussions on crisis and accountability. I would also like to thank the anonymous reviewers at Focaal for their valuable suggestions.

Daniel M. Knight is National Bank of Greece Postdoctoral Research Fellow at the Hellenic Observatory, London School of Economics and Political Science. His ongoing anthropological research concerns economic relations in diverse sociohistorical contexts, adopting a historical approach to understanding the impact of the current economic crisis in Greece. Daniel is currently writing on polytemporality and leading a project on economic sustainability and the Greek photovoltaic energy initiative.

E-mail: d.m.knight@lse.ac.uk

\section{Notes}

1. Bloomberg, 13 May 2011. http://www .bloomberg.com/news/2011-05-13/debt-mayexceed-size-of-economies-this-year-for-greeceportugal-ireland.html

2. Focaal (2008), Social Anthropology (2012), and Cultural Anthropology (2012) have recently hosted extensive debates on the nature of neoliberalism.

3. The Financial Times, 21 October 2011. www .ft.com $/ \mathrm{cms} / \mathrm{s} / . . . / 003$ cbb $92-4 \mathrm{e} 2 \mathrm{~d}-11 \mathrm{df}-\mathrm{b} 48 \mathrm{~d}$ 00144feab49a.html

4. The Telegraph, 16 June 2011. http://www.tele graph.co.uk/finance/economics/8580720/Time line-of-a-crisis-how-Greeces-tragedy-unfolded .html, The Guardian, 5 May 2010. http://www .guardian.co.uk/business/2010/may/05/greecedebt-crisis-timeline

5. Reuters, 13 June 2011. Greece falls to S\&P's lowest rated, default warned.

6. The first rumors of economic instability arose in late 2008 and gathered pace throughout 2009. In May 2010 the eurozone and International Monetary Fund organized the first $£ 95$ billion 
( $€ 110$ billion, $\$ 146.2$ billion) bailout plan for Greece. The national debt stood at 115 percent of GDP and the budget deficit at 13.6 percent.

7. BBC News, 15 February 2010. http://news.bbc .co.uk/1/hi/8536862.stm

8. This notion was invoked in other nations across Europe, such as the Czech Republic and France, in order to motivate people toward political change.

9. Both Klein (2008: 162) and Janet MacGaffey (1998) discuss "crisis opportunism."

\section{References}

Appadurai, Arjun. 1990. Disjuncture and difference in the global cultural economy. Public Culture 2(2): 1-24.

Bryant, Rebecca. 2004. Imagining the modern: The cultures of nationalism in Cyprus. London: I. B. Tauris.

Campbell, Bruce. 2003. Mexican murals in times of crisis. Tucson: University of Arizona Press.

Carrithers, Michael. 2007. Story seeds and the inchoate. Durham Anthropology Journal 14(1): 1-20.

Carrithers, Michael. 2008. From inchoate pronouns to proper nouns: A theory fragment with $9 / 11$, Gertrude Stein, and an East German ethnography. History and Anthropology 19(2): 161-186.

Chomsky, Noam. 1996. Powers and prospects: Reflections on human nature and the social order. London: Pluto Press.

Chomsky, Noam, and David Barsamian. 2001. Propaganda and the public mind: Conversations with Noam Chomsky. London: Pluto Press.

Clarke, John. 2008. Living with/in and without neoliberalism. Focaal: Journal of Global and Historical Anthropology 51(1): 135-147.

Das, Veena. 1995. Critical events: An anthropological perspective on contemporary India. Delhi: Oxford University Press.

di Leo, Luca. 2009. Italy PM Berlusconi: Economic crisis looks particularly bad. http://www .djnewswires.com/eu. (Accessed 12 May 2010).

Fernandez, James. 1986. Persuasions and performances: The play of tropes in culture. Bloomington: University of Indiana Press.

Fernandez, James, ed. 1993. Beyond metaphor: The theory of tropes in anthropology. Palo Alto, CA: Stanford University Press.
Gilbert, Mark, and Liz Capo McCormick. 2011. Europe's "Lehman moment" looms as Greek debt unravels markets: Euro credit. Bloomberg, 16 June.

Gilsenan, Michael. 1996. Lords of the Lebanese marches: Violence and narrative in an Arab society. London: I. B. Tauris.

Goddard, Victoria. 2006. This is history: Nation and experience in times of crisis-Argentina 2001.

History and Anthropology 17(3): 267-286.

Goddard, Victoria. 2010. Two sides of the same coin? World citizenship and local crisis in Argentina. In Dimitrios Theodossopoulos and Elisabeth Kirtsoglou, eds., United in discontent: Local responses to cosmopolitanism and globalization, pp. 124-147. Oxford: Berghahn Books.

Hamilakis, Yannis. 2003. Learn history! Antiquity, national narrative, and history in Greek educational textbooks. In Keith Brown and Yannis Hamilakis, eds., The usable past: Greek metahistories, pp. 39-68. Lanham, MD: Lexington Books.

Harvey, David. 2003. The new imperialism. Oxford: Oxford University Press.

Harvey, David. 2005. A brief history of neoliberalism. Oxford: Oxford University Press.

Hart, Keith, and Horacio Ortiz. 2008. Anthropology in the financial crisis. Anthropology Today 24(6): $1-3$.

Herzfeld, Michael. 1992. The social production of indifference: Exploring the symbolic roots of Western bureaucracy. Chicago: University of Chicago Press.

Herzfeld, Michael. 2011. Crisis attack: Impromptu ethnography in the Greek maelstrom. Anthropology Today 27: 22-26.

Kalb, Don. 2009. Conversations with a Polish populist: Tracing hidden histories of globalization, class, and dispossession in postsocialism (and beyond). American Ethnologist 36(2): 207-223.

Kirtsoglou, Elisabeth. 2010. Conclusion: United in discontent. In Dimitrios Theodossopoulos and Elisabeth Kirtsoglou, eds., United in discontent: Local responses to cosmopolitanism and globalization, pp. 168-180. Oxford: Berghahn Books.

Kirtsoglou, Elisabeth, and Dimitrios Theodossopoulos. 2010. Intimacies of anti-globalization: Imagining unhappy others as oneself in Greece. In Dimitrios Theodossopoulos and Elisabeth Kirtsoglou, eds., United in discontent: Local responses to cosmopolitanism and globalization, $\mathrm{pp}$. 83-102. Oxford: Berghahn Books. 
Klein, Naomi. 2008. The shock doctrine: The rise of disaster capitalism. London: Penguin Books.

Knight, Daniel M. 2011. Prosperity and crisis: Status, accountability and time in central Greece. Unpublished PhD thesis, Department of Anthropology, Durham University.

Knight, Daniel M. 2012a. Cultural proximity: Crisis, time and social memory in Central Greece. History and Anthropology 23(3): 349-374.

Knight, Daniel M. 2012b. Turn of the screw: Narratives of history and economy in the Greek crisis. Journal of Mediterranean Studies 21(1): 53-76.

MacGaffey, Janet. 1998. Creatively coping with crisis: Entrepreneurs in the second economy of Zaire (the Democratic Republic of the Congo). In Barbara Elizabeth McDade and Anita Spring, eds., African entrepreneurship: Theory and reality, pp. 37-50. Gainesville, FL: University of Florida Press.

Miller, Daniel, ed. 1995. Worlds apart: Modernity through the prism of the local. London: Routledge.

Narotzky, Susana. 1997. New directions in economic anthropology. London: Pluto Press.

Narotzky, Susana, and Gavin Smith. 2006. Immediate struggles: People, power, and place in rural Spain. Berkeley: University of California Press.

Ortner, Sherry. 2011. On neoliberalism. Anthropology of this century (1).

Page, Joanna. 2009. Crisis and capitalism in contemporary Argentine film. London: Duke University Press.
Peck, Jamie, and Nik Theodore. 2012. Reanimating neoliberalism: Process geographies of neoliberalisation. Social Anthropology 20(2): 177-185.

Pelkmans, Mathijs, and Rhys Machold. 2011. Conspiracy theories and their truth trajectories. Focaal: Journal of Global and Historical Anthropology 59: 66-80.

Pryce, Vicky. 2012. Greekonomics: The euro crisis and why politicians don't get it. London: Biteback Publications.

Sutton, David. 2003. Poked by the "foreign finger" in Greece: Conspiracy theory or the hermeneutics of suspicion. In Keith Brown and Yannis Hamilakis, eds., The usable Past: Greek metahistories, pp. 191-210. Lanham, MD: Lexington Books.

Theodossopoulos, Dimitrios, ed. 2007. When Greeks think about Turks: The view from anthropology. London: Routledge.

Wacquant, Loïc. 2012. Three steps to a historical anthropology of actually existing neoliberalism. Social Anthropology 20(1): 66-79.

Werbner, Richard.1995. Human rights and moral knowledge: Arguments of accountability in Zimbabwe. In Marilyn Strathern, ed., Shifting contexts: Transformations in anthropological knowledge, pp. 99-116. London: Routledge.

\section{Other sources}

Greek Ministry of Economy and Finance, www.minfin.gr 